\title{
Prognostic Role of ERCC1 Protein Expression and its Correlation with 18F-FDG Uptake on PET in Patients with Resected Non-Small Cell Lung Cancer
}

\author{
Tuba SAHINOGLU', Serkan UYSAL ${ }^{2}$, Ulas KUMBASAR ${ }^{3}$, Sevgen C. ONDER ${ }^{4}$, Riza DOGAN ${ }^{3}$, \\ Ilhan PASAOGLU ${ }^{3}$, Metin DEMIRCIN ${ }^{3}$ \\ ${ }^{1}$ Konya Numune Hospital, Department of Thoracic Surgery, Konya \\ ${ }^{2}$ Bulent Ecevit University, Faculty of Medicine, Department of Thoracic Surgery, Zonguldak \\ ${ }^{3}$ Hacettepe University Faculty of Medicine, Department of Cardiovascular and Thoracic Surgery, Ankara \\ ${ }^{4}$ Hacettepe University Faculty of Medicine, Department of Pathology, Ankara, TURKEY
}

\begin{abstract}
ERCC1 is a protein which is found to be associated with resistance to platinum-based chemotherapy. FDG uptake is considered as a prognostic marker in patients with NSCLC and provides information beyond that of TNM staging. The aim of this study is to examine both prognostic values of ERCC1 expression and 18F-FDG uptake on PET and their relationship in patients who underwent pulmonary resection for NSCLC. Although high expression of ERCC1 was found to be associated with better survival, the difference was not considered as statistically significant $(p=0.067)$. There is a significant survival advantage in ERCC1 $(+)$ patients who did not receive adjuvant therapy $(\mathrm{p}=0.047)$. High maximal standard uptake value (SUVmax) was found to be associated with poor survival (hazard ratio $[\mathrm{HR}]$ : 1.10; $95 \% \mathrm{Cl}, 1.02-1.18 ; \mathrm{p}=0.009$ ). Correlation between ERCC1 expression and mean SUVmax was statistically insignificant $(p=0.915)$. Among patients with SUVmax $\geq 2.5$, ERCC1 positivity was $57.4 \%$ in patients who survived and $29.4 \%$ in patients who died which was statistically significant $(p=0.048$ ). The association between high 18F-FDG uptake on PET and poor outcome was confirmed, but we failed to detect a powerful correlation between ERCC1 expression and SUVmax.
\end{abstract}

Keywords: ERCC1, Survival, Positron emission tomography

\section{ÖZET}

\section{Küçük Hücreli Dışı Akciğer Kanseri'nde ERCC1'in Prognostic Rolü ve 18F-FDG Tutulumu ile Korelasyonu}

ERCC1 protein pozitifliği ile platin bazlı kemoterapi arasında direnç olduğu bulunmuştur. FDG tutulumunun ise KHDAK'da prognostik bir belirteç olduğu, TNM sınıflamasının ötesinde prognostik bilgi verdiği kabul edilmektedir. Bu çalışmanın amacı, KHDAK nedeniyle akciğer rezeksiyonu uy-gulanmış olan hastalarda hem ERCC1 proteininin prognostik değerinin hem de ERCC1 ekspresyonunun PET'te 18F-FDG tutulumu ile olan korelasyonunu araştııımasıdır. KHDAK tanısıyla PET sonrası akciğer rezeksiyonu uygulanmış olan 71 hasta retrospektif olarak incelendi. ERCC1 ekspresyonu olan hastaların sağkalımı istatistiksel olarak anlamlı olmasa da daha iyi bulundu $(p=0.067)$. Adjuvan tedavi almayan hastalarda ERCC1 pozitif hastalarda anlamlı sağkalım avantajı olduğu görüldü ( $p=0.047)$. Yüksek SUVmax değerleri kötü prognozu gösterdi (hazard ratio [HR]: 1.10; 95\% Cl, 1.02-1.18; $p=0.009$ ). ERCC1 ekspresyonu ile ortalama SUVmax değerleri arasında anamlı korelasyon saptanmadı ( $p=0.915)$. SUVmax $\geq 2.5$ olan hastalarda, ölen hastalarda ERCC1 pozitifliği \%57.4, yaşayan hastalarda \%29.4 olarak saptandı ( $p=0.048$ ). Yüksek 18F-FDG tutulumu değerleri ile kötü prognoz ilişkisi bu çalışma ile tekrar gösterilmiş oldu. Ancak, ERCC1 ekspresyonu ile SUVmax değerleri arasında güçlü bir korelasyon saptanamadı.

Anahtar Kelimeler: ERCC1, Sağkalım, Positron emisyon tomografisi 


\section{INTRODUCTION}

Lung cancer is the leading cause of cancer-related mortality worldwide which accounts for almost 1.3 million deaths a year. ${ }^{1}$ Almost $85 \%$ of lung cancer cases are non-small cell lung cancer (NSCLC) which is moderately chemosensitive with a 5 -year survival rate of nearly $15 \%$ for all stages. ${ }^{2}$ Clinical outcome can be heterogeneous among patients with NSCLC. ${ }^{3}$ The ability to accurately predict subsets with poor outcomes is therefore important consideration as this could be used to help select appropriate patients for specific treatment strategies.

Platinum-based adjuvant chemotherapy has been widely accepted as the standard of care after surgical resection of NSCLC within stages IB to IIIA. ${ }^{4,5}$ However, a large population remains unresponsive to chemotherapy due to drug resistance. ${ }^{6}$ Therefore, identifying biomarkers which may help clinicians to choose specific drugs for sensitive patients has been of increasing interest. Some recent studies have evaluated the prognostic significance of Nucleotide excision repair (NER) pathway biomarkers. ${ }^{7,8}$ Excision repair cross-complementation group 1 (ERCC1) which is involved in the NER system, specifically removes platinum adducts of DNA and is found to be associated with resistance to platinum-based chemotherapy. ${ }^{9-11}$

Fluorodeoxyglucose positron emission tomography (18F-FDG-PET) has become an important non-invasive tool for diagnosing and staging NSCLC. Since metabolically active cells selectively take up and trap fluoridated glucose, the intensity of FDG uptake correlates with tumor growth rates and it has gained acceptance as a prognostic marker in patients with NSCLC and provides prognostic information beyond that of TNM staging alone. ${ }^{12-14}$

Several studies demonstrated that the maximal standardized uptake (SUVmax) measurement on $18 \mathrm{~F}-\mathrm{FDG}-\mathrm{PET}$ is related with expression levels of some biomarkers, such as Glut 1 and vascular endothelial growth factor (VEGF). ${ }^{15,16}$ However, there are few studies investigating the correlation between 18F-FDG uptake and ERCC1 expression in NSCLC. ${ }^{17,18}$ In this study, we examined both the prognostic values of ERCC1 expression and
18F-FDG uptake on PET and their relationship in patients who underwent pulmonary resection for NSCLC.

\section{PATIENTS AND METHODS}

We studied 100 patients who underwent 18F-FDG PET and lung resection for NSCLC between January 2008 and February 2011. This study has been approved by the Ethical Committee of Hacettepe University Faculty of Medicine and written consent has been waived. Data were retrospectively compiled from individual patient notes, electronic patient records and pathology reports. We ex-cluded 29 patients because of incomplete data leaving 71 patients for analysis. 18F-FDG PET was performed as part of the preoperative work-up. Surgical specimens were analysed and classified according to the World Health Organization (WHO) classification by a lung pathologist blinded to PET results. Pathologic staging was characterised according to the seventh edition of the American Joint Committee on Cancer TNM staging system.

Of the 71 patients included, 57 (80.3\%) were male and $14(19.7 \%)$ were female. The mean age was 60 years (range, 35 to 80). Patients who took neoadjuvant chemotherapy were not included to this study. Thirty-three patients (46.5\%) who had N1 and N2 disease (Stage II-IIIA) were treated with platinum-based doublet adjuvant chemotherapy during follow-up. Additionally, patients with N2 disease were given adjuvant radiotherapy. The median follow-up time was 5-years. The clinicopathologic characteristics of patients are summarised in Table 1. Immunohistochemical staining was performed with a mouse monoclonal antibody against ERCC1 (ERCC1[8F1] 2356 Mouse monoclonal [8F1], Novus Biologicals, Littleton, CO). Intensity of staining was scored as the following: 0 (none), 1 (weak), 2 (intermediate), 3 (strong). The percentage of positive cells was scored as $1(0 \%$ to $25 \%$ ), 2 (26\% to $50 \%$ ), 3 (51\% to $75 \%$ ) and 4 ( $76 \%$ to $100 \%$ ). The immunohistochemistry (IHC) score ranging from 0 to 12 was obtained by multiplying the intensity and the percentage of positive cells and ERCC1 expression was judged as positive when the IHC score was equal to or greater than 3 . 


\begin{tabular}{|c|c|c|}
\hline Variable & No. of patients & $\%$ \\
\hline \multicolumn{3}{|l|}{ Age } \\
\hline$\leq 60$ years & 31 & 43.7 \\
\hline$>60$ years & 40 & 56.3 \\
\hline \multicolumn{3}{|l|}{ Gender } \\
\hline Male & 57 & 80.3 \\
\hline Female & 14 & 19.7 \\
\hline \multicolumn{3}{|l|}{ Smoking } \\
\hline Yes & 60 & 84.5 \\
\hline No & 11 & 15.5 \\
\hline \multicolumn{3}{|l|}{ SUVmax } \\
\hline$<2.5$ & 7 & 9.9 \\
\hline$\geq 2.5$ & 64 & 90.1 \\
\hline \multicolumn{3}{|l|}{ Operation } \\
\hline Pneumonectomy & 11 & 15.5 \\
\hline Lobectomy & 59 & 83.1 \\
\hline Sleeve lobectomy & 1 & 1.4 \\
\hline \multicolumn{3}{|l|}{ Histology } \\
\hline Adenocarcinoma & 33 & 46.5 \\
\hline Squamous cell carcinoma & 26 & 36.6 \\
\hline Large cell carcinoma & 4 & 5.6 \\
\hline Carcinoid tumor & 2 & 2.8 \\
\hline Pleomorphic carcinoma & 5 & 7.0 \\
\hline Adenosquamous carcinoma & 1 & 1.4 \\
\hline \multicolumn{3}{|l|}{ Pathologic stage } \\
\hline IA & 17 & 23.9 \\
\hline IB & 14 & 19.7 \\
\hline$\| A$ & 13 & 18.3 \\
\hline IIB & 8 & 11.3 \\
\hline IIIA & 14 & 19.7 \\
\hline IIIB & 1 & 1.4 \\
\hline IV & 4 & 5.6 \\
\hline \multicolumn{3}{|l|}{ ERCC1 } \\
\hline Positive & 37 & 52.1 \\
\hline Negative & 34 & 47.9 \\
\hline
\end{tabular}

Statistical analysis was performed using SPSS software, version 18.0 (SPSS Inc, Chicago, IL). Normality of the numeric variables was analysed by Shapiro Wilks test. Continuous variables were tested using student t-test or one way analysis of the variable (ANOVA) test. Pearson Chi-Square test was used to examine the association of two categorical variables. Kaplan Meier product limit estimation analysis and Cox proportional hazard regression analysis were done to evaluate the ef- fects of clinical and pathologic variables on survival. A p-value $<0.05$ was considered statistically significant.

\section{RESULTS}

Tumor specimens of 71 patients were analysed for ERCC1 expression. Among the 71 samples, the incidence rate of high ERCC1 expression was $52.1 \%$ (37/71). When the correlation between such expression and below mentioned clinical variables assessed, no correlation was observed between ERCC1 positivity and age, gender, smoking status, coexisting diseases, type of surgical resection, tumor histology, tumor diameter and pathologic stage (Table 2). In ERCC1 (-) patients 1, 3 and 5-year survival rates were $87.6 \%, 61.7 \%$ and $47.0 \%$, respectively; whereas, in ERCC1 (+) patients same rates were $93.8 \%, 81.6 \%$ and $81.6 \%$, respectively. Mean overall survival was $43.8 \pm 5.2$ months in ERCC1 (-) patients, and $43.9 \pm 2.9$ months in ERCC1 (+) patients. Although high expression of ERCC1 was found to be associated with better survival, the difference was not considered as statistically significant $(\mathrm{p}=0.067)$ (Figure 1).

The SUVmax of the tumors in 71 patients ranged from 1.0 to 26.4 (mean $10.44 \pm 6.05$ ). In our study, we took the cut-off SUV value as 2.5 in line with other studies in the literature and $90.1 \%$ of patients was detected with a value of $\geq 2.5$. $^{18,19}$ No relationship was detected between SUVmax and age, gender, smoking status, tumor histology, pathologic stage. Nevertheless, mean SUVmax was statistically higher in patients with tumor diameter $\geq 3 \mathrm{~cm}(\mathrm{p}<0.0001)$. High SUVmax was found to be associated with poor survival $(\mathrm{p}=0.047)$. Table 3 shows the relationship of SUVmax with different variables.

The correlation between ERCC1 expression and mean SUVmax was statistically insignificant $(\mathrm{p}=$ 0.915). However, among patients with SUVmax $\geq 2.5$, ERCC1 positivity was $57.4 \%$ in patients who survived and $29.4 \%$ in patients who died which was statistically significant $(\mathrm{p}=0.048)$ (Table 4). The impact of ERCC1 expression on survival was also analysed separately in relation to patients' receiving adjuvant chemotherapy or not. In patients 
International Journal of Hematology and Oncology

\begin{tabular}{|c|c|c|c|}
\hline Variable & ERCC1 (+) (\%) & ERCC1 (-) (\%) & p Value \\
\hline \multicolumn{4}{|l|}{ Age } \\
\hline$\leq 60$ years & $13(41.9)$ & $18(58.1)$ & 0.102 \\
\hline$>60$ years & $24(60.0)$ & $16(40.0)$ & \\
\hline \multicolumn{4}{|l|}{ Gender } \\
\hline Male & $31(54.4)$ & $26(45.6)$ & 0.317 \\
\hline Female & $6(42.9)$ & $8(57.1)$ & \\
\hline \multicolumn{4}{|l|}{ Smoking } \\
\hline Yes & 32 (53.3) & $28(46.7)$ & 0.438 \\
\hline No & $5(45.5)$ & $6(54.5)$ & \\
\hline \multicolumn{4}{|l|}{ SUVmax } \\
\hline$<2.5$ & $5(71.4)$ & 2 (28.6) & 0.281 \\
\hline$\geq 2.5$ & $32(50.0)$ & $32(50.0)$ & \\
\hline \multicolumn{4}{|l|}{ Type of resection } \\
\hline Pneumonectomy & $5(45.4)$ & $6(54.6)$ & 0.383 \\
\hline Lobectomy & $30(50.8)$ & $29(49.2)$ & \\
\hline Sleeve lobectomy & $1(100.0)$ & $-(0.0)$ & \\
\hline \multicolumn{4}{|l|}{ Histology } \\
\hline Adenocarcinoma & $15(45.5)$ & $18(54.5)$ & 0.741 \\
\hline Squamous cell carcinoma & $16(61.5)$ & $10(38.5)$ & \\
\hline Large cell carcinoma & $2(50.0)$ & $2(50.0)$ & \\
\hline Carcinoid tumor & $1(50.0)$ & $1(50.0)$ & \\
\hline Pleomorphic carcinoma & $2(40.0)$ & $3(60.0)$ & \\
\hline Adenosquamous carcinoma & $1(100.0)$ & $-(0.0)$ & \\
\hline \multicolumn{4}{|l|}{ Tumor diameter (cm) } \\
\hline$<3$ & 19 (57.6) & $14(42.4)$ & 0.268 \\
\hline$\geq 3$ & $18(47.4)$ & 20 (52.6) & \\
\hline \multicolumn{4}{|l|}{ Pathologic stage } \\
\hline $\mathrm{IA}$ & 10 (58.8) & 7 (41.2) & 0.149 \\
\hline IB & $10(71.4)$ & 4 (28.6) & \\
\hline$\| \mathrm{A}$ & $8(61.5)$ & $5(38.5)$ & \\
\hline IIB & $3(37.5)$ & $5(62.5)$ & \\
\hline IIIA & $6(42.9)$ & $8(57.1)$ & \\
\hline IIIB & - (0.0) & 1 (100.0) & \\
\hline IV & - (0.0) & 4 (100.0) & \\
\hline \multicolumn{4}{|l|}{ Survival } \\
\hline Dead & $5(27.8)$ & $13(72.2)$ & 0.067 \\
\hline Alive & $32(60.4)$ & 21 (39.6) & \\
\hline
\end{tabular}

who received adjuvant therapy, 5-year survival in ERCC1 (+) and (-) patients were $66.7 \%$ and $52.6 \%$, respectively $(\mathrm{p}=0.637)$. In patients who did not receive adjuvant therapy, 5-year survival in ERCC1 $(+)$ and (-) patients were $85.3 \%$ and $30.3 \%$, respectively $(\mathrm{p}=0.047)$ (Figure 2$)$. The effects of clinical and pathologic variables such as ERCC1 expression, age, adjuvant therapy status, high SUVmax levels, sex and histologic type on survival was also analysed with multivariate analysis and illustrated in Table 5. Above these variables solely ERCC1 negativity was found to be statistically associated with poor survival (hazard ratio [HR]: $3.043 ; 95 \%$ CI, 1.007-9.198; $\mathrm{p}=0.049$ ).

\section{DISCUSSION}

The present study evaluated the prognostic values of ERCC1 expression and SUVmax on 18FFDG PET and their relationship in patients who 


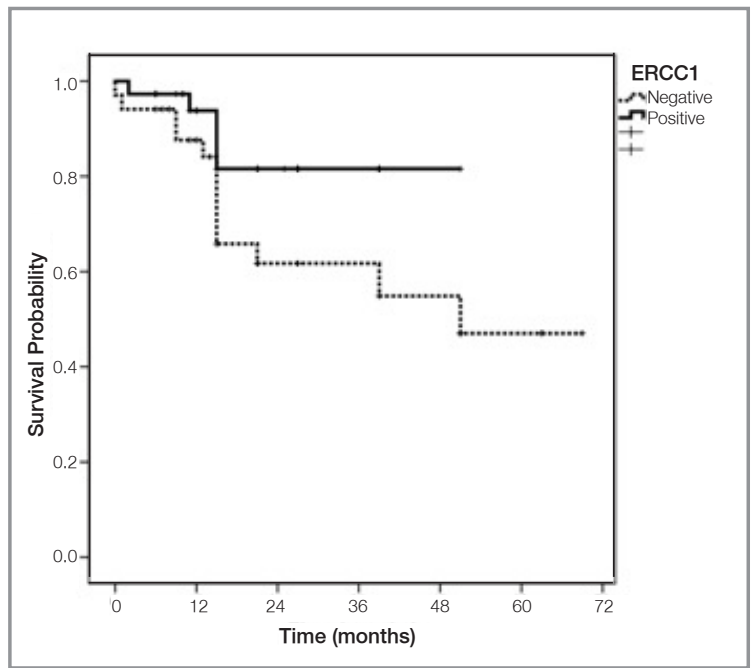

Figure 1. Kaplan-Meier survival analysis of ERCC1 for all patients underwent pulmonary resection for NSCLC. Several studies have investigated a number of tumor biomarkers for prognostic and predictive utility in NSCLC. ${ }^{20-23}$ One of the most prominent among these biomarkers is ERCC1 which is a critical protein involved in nucleotide excision repair and removes platinum-DNA adducts. Thus, expression of ERCC1 reflects DNA repair capacity and platinum-based drug resistance. ${ }^{8,21,22}$ The role of ERCC1 expression on patient outcome in NSCLC has been evaluated by several studies. In most of the studies based on patients who received chemotherapy for advanced stage NSCLC, high ERCC1 expression was found to be associated with poor prognosis reflecting the role of this biomarker on chemotherapy resistance. ${ }^{20,21,23-26}$ Olaussen et al. showed in their study that high ERCC1 protein ex-

\begin{tabular}{|c|c|c|c|}
\hline Variable & No. of patients & SUVmax (mean $\pm S D)$ & p-value \\
\hline \multicolumn{4}{|l|}{ Age } \\
\hline$\leq 60$ years & 31 & $10.14 \pm 6.1$ & 0.709 \\
\hline$>60$ years & 40 & $10.68 \pm 6.0$ & \\
\hline \multicolumn{4}{|l|}{ Gender } \\
\hline Male & 57 & $11.10 \pm 5.8$ & 0.067 \\
\hline Female & 14 & $7.79 \pm 6.4$ & \\
\hline \multicolumn{4}{|l|}{ Smoking } \\
\hline Yes & 60 & $11.04 \pm 5.6$ & 0.053 \\
\hline No & & 11 & $7.21 \pm 7.2$ \\
\hline \multicolumn{4}{|l|}{ Tumor diameter (cm) } \\
\hline$<3$ & $7.03 \pm 4.5$ & $<0.0001$ & \\
\hline$\geq 3$ & $13.41 \pm 5.6$ & & \\
\hline \multicolumn{4}{|l|}{ Histology } \\
\hline Adenocarcinoma & 34 & $9.15 \pm 6.2$ & 0.085 \\
\hline Others & 37 & $11.63 \pm 5.7$ & \\
\hline Squamous cell carcinoma & 27 & $10.92 \pm 5.0$ & 0.604 \\
\hline Others & 44 & $10.15 \pm 6.6$ & \\
\hline \multicolumn{4}{|l|}{ ERCC1 } \\
\hline Positive & 37 & $10.37 \pm 6.8$ & 0.915 \\
\hline Negative & 34 & $10.52 \pm 5.1$ & \\
\hline \multicolumn{4}{|l|}{ Pathologic stage } \\
\hline IA & 17 & $6.78 \pm 3.4$ & 0.07 \\
\hline $\mathrm{IB}$ & 14 & $11.72 \pm 6.7$ & \\
\hline$\| A$ & 13 & $10.61 \pm 5.2$ & \\
\hline IIB & 8 & $14.73 \pm 6.2$ & \\
\hline IIIA & & 14 & $11.46 \pm 6.2$ \\
\hline IIIB & & 1 & $21.30 \pm 0.0$ \\
\hline IV & 4 & $6.17 \pm 4.5$ & \\
\hline \multicolumn{4}{|l|}{ Survival } \\
\hline Dead & 18 & $12.88 \pm 7.2$ & 0.047 \\
\hline Alive & 53 & $9.61 \pm 5.4$ & \\
\hline
\end{tabular}



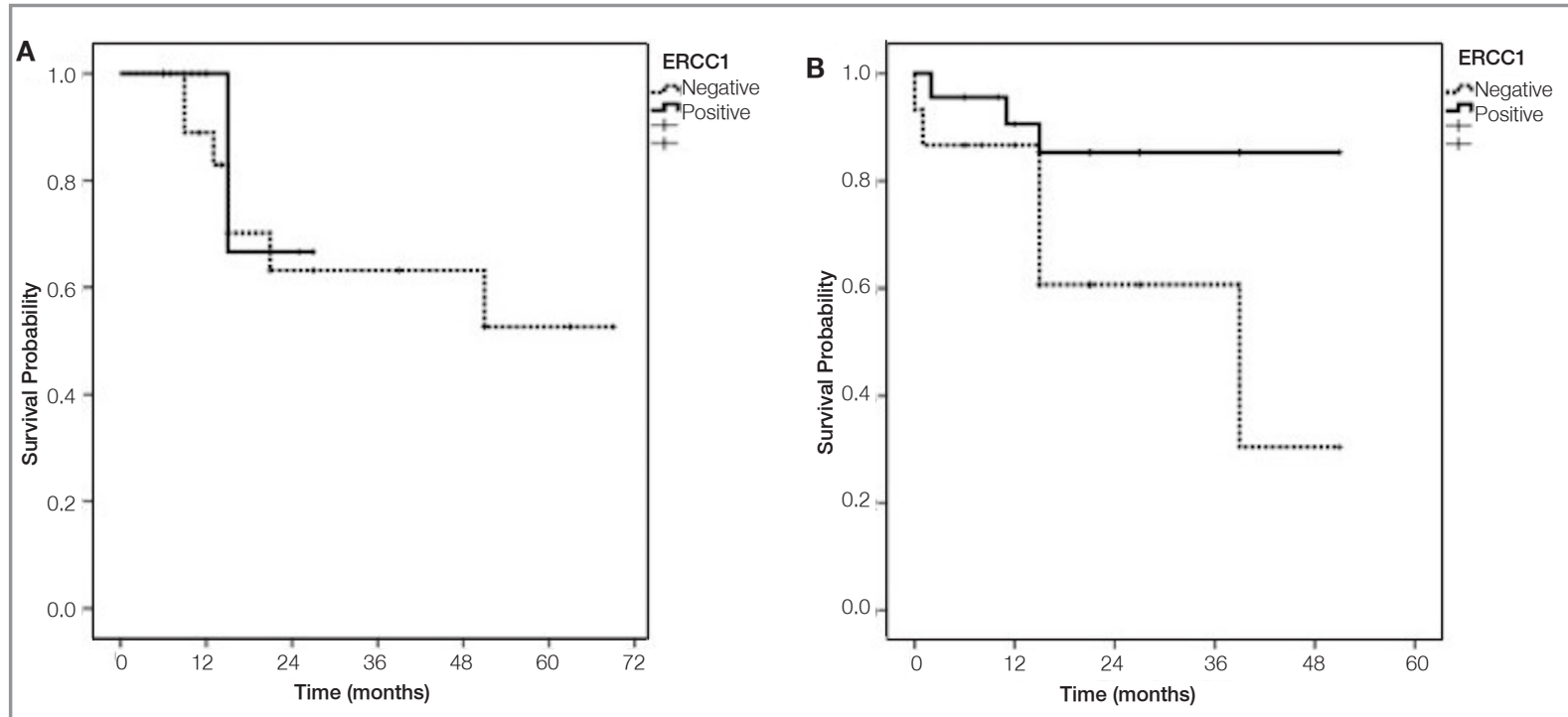

Figure 2. Kaplan-Meier survival analysis of ERCC1. (A) Survival rates for patients who received adjuvant chemotherapy. (B) Survival rates for patients who did not received adjuvant chemotherapy

pression was associated with improved survival in patients who did not receive chemotherapy. ${ }^{27}$

Jiang et al also demonstrated in their meta analysis that high ERCC1 expression was associated with prolonged survival in patients with early stage NSCLC who received surgery alone. Furthermore, there was no difference in survival between high and low ERCC1 levels in patients received surgery plus adjuvant chemotherapy. In contrast, high ERCC1 expression was associated with shorter survival and lower response to chemotherapy in advanced NSCLC patients who received palliative chemotherapy in their study. ${ }^{28}$

In our study, when patients who underwent radical resection for early stages of NSCLC were evaluated, ERCC1 (+) patients had better survival although statistically insignificant $(p=0.067)$. This finding was also confirmed with the multivariate analysis which showed poorer survival in ERCC1
(-) patients. Our study demonstrated a significant survival advantage in ERCC1 (+) patients who did not receive adjuvant therapy $(\mathrm{p}=0.047)$. We could not identify any survival advantage according to ERCC1 expression in patients who received adjuvant chemotherapy, which may be due to ERCC1 related chemotherapy resistance.

Previous studies described SUV measurement on 18F-FDG PET as a predictor of survival in NSCLC and identified high SUV as poor prognostic factor. ${ }^{14,29,30}$ Our results also showed that high SUVmax was associated with poor survival. In this study, we also postulated whether 18F-FDG uptake could reflect the level of ERCC1 protein within the tumor cells. Some recent studies investigated the relationship between 18F-FDG PET and various tumor biomarkers. ${ }^{15-18}$ Recently, Duan et al. demonstrated a significant correlation between SUVmax and ERCC1 expression and revealed that SUVmax

\begin{tabular}{|c|c|c|c|c|}
\hline Variable & ERCC1 (+) & ERCC1 (-) & Pearson Chi-Square & p-value \\
\hline \multicolumn{5}{|c|}{ SUVmax $\geq 2.5$} \\
\hline Dead & 5 (29.4\%) & $12(70.6 \%)$ & 3.925 & 0.048 \\
\hline Alive & 27 (57.4\%) & $20(42.6 \%)$ & & \\
\hline
\end{tabular}




\begin{tabular}{|c|c|c|c|}
\hline Variable & [HR] & $95 \% \mathrm{Cl}$ & p value \\
\hline ERCC1 negativity & 3.043 & $1.007-9.198$ & 0.049 \\
\hline Age $>60$ & 2.632 & $0.892-7.763$ & 0.080 \\
\hline Adjuvant therapy & 0.934 & $0.352-2.480$ & 0.891 \\
\hline SUVmax $>2.5$ & 0.691 & $0.086-5.522$ & 0.727 \\
\hline Sex (Male) & 4.912 & $0.636-37.950$ & 0.127 \\
\hline Histology & 0.551 & $0.185-1.638$ & 0.283 \\
\hline
\end{tabular}

of ERCC1 (+) cases were significantly higher than that of ERCC1 (-) cases. However, they failed to detect a strong correlation when multiple stepwise regression was performed. ${ }^{31}$ Thus, their study remains inconclusive whether SUVmax could be used to determine ERCC1 expression. Kaira et al. also examined the relationship between the expression level of ERCC1 and 18F-FDG uptake on PET in various thoracic neoplasms including NSCLC. Although they found high expression of ERCC1 in squamous cell carcinoma of the lung, a statistically significant correlation was reported only in thymic epithelial tumors. Thus, they suggested the SUVmax by $18 \mathrm{~F}-F D G$ uptake in patients with thymoma as a feasible alternative for ERCC1 expression. ${ }^{31} \mathrm{In}$ our study, no significant correlation was detected between ERCC1 expression and mean SUVmax. However, among patients with SUVmax $\geq 2.5$, ERCC1 positivity was $57.4 \%$ for patients who stayed alive, whereas it was $29.4 \%$ for patients who could not survive which was found statistically significant $(\mathrm{p}=0.048)$.

Since different techniques were used in various studies to detect ERCC1 expression, further studies with standardised and optimised protocols are required to validate the utility of ERCC1 as a prognostic and predictive marker. Our study is a retrospective analysis with a limited sample size which also includes heterogeneous groups with or without adjuvant therapy.

In conclusion, ERCC1 expression had an influence on survival especially in patients who under-went pulmonary resection and did not receive adjuvant therapy for NSCLC. We confirmed the association between high 18F-FDG uptake on PET and poor outcome, but failed to detect a powerful correlation between ERCC1 expression and SUVmax. Therefore, we believe that future prospective, welldesigned studies with standardised biomarker assays and larger cohorts are needed to evaluate the role of ERCC1 as a potential prognostic biomarker and its association with 18F-FDG uptake on PET in NSCLC.

\section{REFERENCES}

1. DeSantis CE, Lin CC, Mariotto AB, et al. Cancer treatment and survivorship statistics. CA Cancer J Clin 64: 252-271, 2014.

2. Molina JR, Yang P, Cassivi SD, et al. Non-small cell lung cancer: epidemi-ology, risk factors, treatment, and survivorship. Mayo Clin Proc 83: 584-594, 2008.

3. Molina JR, Adjei AA, Jett JR. Advances in chemotherapy of non-small cell lung cancer. Chest 130: 1211-1219, 2006.

4. D'Addario G, Felip E, Group EGW. Non-small-cell lung cancer: ESMO clinical recommendations for diagnosis, treatment and follow-up. Ann Oncol 4: 68-70, 2004.

5. Saisho S, Yasuda K, Maeda A, et al. Post-recurrence survival of patients with non-small-cell lung cancer after curative resection with or without induction/adjuvant chemotherapy. Interact Cardiovasc Thorac Surg 16: 166-172, 2013.

6. Stewart DJ, Chiritescu G, Dahrouge S, et al. Chemotherapy dose response relationships in non-small cell lung cancer and implied resistance mechanisms. Cancer Treat Rev 33: 101137, 2007.

7. Simon GR, Sharma S, Cantor A, et al. ERCC1 expression is a predictor of survival in resected patients with non-small cell lung cancer. Chest 127: 978-983, 2005.

8. Olaussen KA, Dunant A, Fouret $P$, et al. DNA repair by ERCC1 in non-small-cell lung cancer and cisplatin-based adjuvant chemotherapy. N Engl J Med 355: 983-991, 2006.

9. Altaha R, Liang $X, Y u J J$, Reed E. Excision repair cross complementing-group 1: gene ex-pression and platinum resistance. Int J Mol Med 14: 959-970, 2004. 
10. Azuma K, Komohara Y, Sasada T, et al. Excision repair crosscomplementation group 1 predicts progression-free and overall survival in non-small cell lung cancer patients treated with platinum-based chemotherapy. Cancer Sci 98: 1336-1343, 2007.

11. Kaira K, Yamamoto N. Prognostic and predictive factors in resected non-small cell lung cancer. Expert Opin Med Diagn 4: 373-381, 2010.

12. de Geus-Oei LF, van Krieken JH, Aliredjo RP, et al. Biological correlates of FDG uptake in non-small cell lung cancer. Lung Cancer 55: 79-87, 2007.

13. de Geus-Oei LF, van der Heijden HF, Corstens FH, Oyen WJ. Predictive and prognostic value of FDG-PET in non-small cell lung cancer: a systematic review. Cancer 110: 1654-1664, 2007.

14. Berghmans T, Dusart M, Paesmans M, et al. Pri-mary tumor standardized uptake value (SUVmax) measured on fluorodeoxyglucose positron emis-sion tomography (FDG-PET) is of prognostic value for survival in non-small cell lung cancer (NSCLC): a systematic review and meta-analysis (MA) by the European Lung Cancer Working Party for the IASLC Lung Cancer Staging Project. J Thorac Oncol 3: 6-12, 2008.

15. Higashi K, Ueda Y, Sakurai A, et al. Correlation of Glut-1 glucose transporter expression with [(18)F]FDG uptake in nonsmall cell lung cancer. Eur J Nucl Med 27: 1778-1785, 2000.

16. Kaira K, Oriuchi N, Shimizu K, et al. Correlation of angio-genesis with 18F-FMT and 18F-FDG uptake in non-small cell lung cancer. Cancer Sci 100: 753-758, 2009.

17. Kaira K, Endo M, Shukuya T, et al. (1)(8)F-FDG uptake on PET could be a predictive marker of excision repair cross-complementation group 1 (ERCC1) ex-pression in patients with thoracic neoplasms? Neoplasma 59: 257-263, 2015.

18. Duan XY, Wang W, Wang JS, et al. Fluorodeoxyglucose positron emission tomography and chemotherapy-related tumor marker expression in non-small cell lung cancer. BMC Cancer 13: 546-553, 2013.

19. Taylor MD, Smith PW, Brix WK, et al. Fluorode-oxyglucose positron emission tomography and tumor marker expression in non-small cell lung cancer. J Thorac Cardiovasc Surg 137: 43-48, 2009

20. Vassalou H, Stathopoulos E, Fiolitaki G, et al. Excision-repaircross-complement-1 protein as a prognostic factor in patients with advanced non-small cell lung cancer treated with platinum-based first-line chemotherapy. Lung Cancer 82: 324329, 2013.

21. Sad LM, Younis SG, Elity MM. Prognostic and predictive role of ERCC1 protein expres-sion in locally advanced stage III non-small cell lung cancer. Med Oncol 31: 58-66, 2014.

22. Cai $Y$, Yan $X$, Zhang $G$, et al. The predictive value of ERCC1 and p53 for the effect of panobinostat and cisplatin combination treatment in NSCLC. Oncotarget 6:9000-9005, 2015.

23. Sun S, Shi W, Wu Z, et al. Prognostic significance of the mRNA ex-pression of ERCC1, RRM1, TUBB3 and TYMS genes in patients with non-small cell lung cancer. Exp Ther Med 10: 937-41, 2015.
24. Holm B, Mellemgaard A, Skov T, Skov BG. Different impact of excision repair cross-complementation group 1 on survival in male and female patients with inoperable non-small cell lung cancer treated with carboplatin and gemcitabine. J Clin Oncol 27: 4254-4259, 2009.

25. Ikeda S, Takabe K, Suzuki K. Expression of ERCC1 and class Illbeta tubulin for predicting effect of carboplatin/paclitaxel in patients with advanced inoperable non-small cell lung cancer. Pathol Int 59: 863-867, 2009.

26. Lee HW, Choi YW, Han JH, et al. Expression of excision repair cross-complementation group 1 protein predicts poor outcome in advanced non-small cell lung cancer patients treated with platinum-based doublet chemotherapy. Lung Cancer 65: 377-382, 2009.

27. Olaussen KA, Mountzios G, Soria JC. ERCC1 as a risk stratifier in platinum-based chemotherapy for non-small cell lung cancer. Curr Opin Pulm Med 13: 284-289, 2007.

28. Jiang J, Liang X, Zhou X, et al. ERCC1 expression as a prognostic and predictive factor in patients with non-small cell lung cancer: a meta-analysis. Mol Biol Rep 39: 6933-6942, 2012.

29. Higashi K, Ueda Y, Arisaka Y, et al. 18F-FDG uptake as a biologic prognostic factor for recurrence in patients with surgically resected non-small cell lung cancer. J Nucl Med 43: 39-45, 2001.

30. Sasaki R, Komaki R, Macapinlac H, et al. [18F]fluorodeoxyglucose uptake by positron emission tomography predicts outcome of non-small-cell lung cancer. J Clin Oncol 23: 11361143, 2005.

31. Kaira K, Endo M, Shukuya T, et al. FDG uptake on PET could be a predictive marker of excision repair cross-complementation group 1 (ERCC1) expres-sion in patients with thoracic neoplasms? Neoplasma 59: 257-263, 2012.

\section{Correspondence:}

Dr. Ulas KUMBASAR

Hacettepe Universitesi Tip Fakultesi

Kardiyovaskuler ve Torasik Cerrahi Anabilim Dali

Sihhiye, ANKARA / TURKEY

Tel: (+90-312) 3051774

Fax: (+90-312) 3117377

e-mail: ulaskumbasar@gmail.com 